\title{
Geographic Information System of Distribution of Poor Households in the Palaran District
}

\author{
Kevin Rivaldi Sosang \\ Software Enginering Technology, \\ Agricultural Polytechnic of \\ Samarinda, Samarinda, 7542, \\ Indonesia \\ kevinsosang@gmail.com
}

\author{
Syafei Karim (iD* \\ Software Enginering Technology, \\ Agricultural Polytechnic of \\ Samarinda, Samarinda, 7542, \\ Indonesia \\ syfei.karim@gmail.com \\ *Corresponding Author
}

\author{
F.V Astrolabe Sian Prasetya (i) \\ Geomatics Technology, \\ Agricultural Polytechnic of \\ Samarinda, Samarinda, 7542, \\ Indonesia \\ astrolabesp@politanisamarinda.ac.id
}

Submitted: 2021-10-01; Revised: 2021-10-01; Accepted: 2022-02-10; Published: 2022-03-01

\begin{abstract}
Related to poverty, an important issue that needs attention is the relatively large number of poor people. This relatively large number of poor people is mainly associated with poverty alleviation efforts, both through funding by the central government and local governments. However, such a high-quantity effort has not been able to significantly alleviate poverty. This can be seen from the worsening quality of the poor. So to get these results, a geographical information system (GIS) is needed or commonly known as a geographic information system (GIS) so that data on poor households is right on target. A geographic Information System is a tool that can be used to assist in analyzing the condition of an area in the field of the population to determine the level of welfare of its population. GIS can also convey information in the form of thematic maps so that the condition of an area towards poverty can be presented in the form of visualization of thematic maps and can make it easier for users to understand the information conveyed. The expected result is that this GIS application can make it easier to provide information to the public about the existence of poor households in the Palaran District.
\end{abstract}

Keywords-Geographic Information System, Poor Household, Samarinda.

\section{INTRODUCTION}

Two central issues of development problems that still haunt the Indonesian nation today are unemployment and poverty. These two problems are related to each other. In many cases that often occur, poverty begins with a lack of access for productive workers to employment opportunities. On the other hand, poverty hinders access to education and health, which in turn has an impact on the low quality of human resources.

Related to poverty, an important issue that needs attention is the relatively large number of poor people. This relatively large number of poor people is mainly associated with poverty alleviation efforts, both through funding by the central government and local governments. However, such a high-quantity effort has not been able to significantly alleviate poverty. This can be seen from the worsening quality of the poor. This is because the poverty alleviation efforts that have been carried out so far have not been running according to the target. So to get this information, a geographical information system (GIS) is needed, or commonly known as a geographic information system (GIS) so that data on poor households is right on target (Adiana and Ni Luh Karmini 2012).

A geographic Information System is a tool that can be used to assist in analyzing the condition of an area in the field of the population to determine the level of welfare of its population. GIS can also convey information in the form of thematic maps so that the condition of an area towards poverty can be presented in the form of visualization of thematic maps and can make it easier for users to understand the information conveyed (Mardiana 2011).

\section{LITERATURE REVIEW}

Some of the literature studies used as guidelines for making this thesis are as follows:

The increase in population is driven by migration flows, due to the high expectations seen by migrants for the rapid development of the city of Pekanbaru. With this amount, the population density of the city increases. This population density raises new problems, especially in the field of services, provision of social facilities, and public facilities. One of the negative impacts of the increase in population indirectly has an impact on the number of poor people in Pekanbaru. A geographic Information System is a tool that can be used to assist in analyzing the condition of an area in the field of the population to determine the level of welfare of its population (Mardiana 2011).

Bukittinggi is one of the big cities in West Sumatra with a high poverty rate. Bukittinggi ranks fourth highest in West Sumatra with $4.96 \%$ of the population being poor. Bukittinggi is recorded to have 2,694 poor households spread over 3 sub-districts with 24 urban villages. Phun Tembok Village ranks third for the poorest households. The existing 163 poor households are spread over an area of approximately $70.9 \mathrm{~km} 2$. The scattered locations and inaccurate information on each poor household resulted in the poverty alleviation program are not well-targeted. For this reason, a web-based information system based on the location of poor households in Puhun Tembok Village was built. The software development method used is the 
waterfall method. The application has 7 functional requirements, including searching for poor households based on RW, assistance received, searching for the nearest poor household, and routes to poor households. The functionality of the application was tested by 5 testers. The test results show that the 7 functional requirements designed have been met by the application (Fithriyyah, Akbar, and Suryamen 2016).

Perum Bulog is in charge of delivering Raskin to distribution points in 23 sub-districts in Pidie Regency, to save time and cost in distributing Raskin Perum Bulog needs to know the distance between warehouses and distribution points for Raskin, therefore it is necessary to have a Geographic information system that can produce accurate information. Fast and accurate. In this final project, the author builds a web-based geographic information system for the distribution of Raskin at Perum Bulog, Pidie Regency. By using a geographic information system in determining the location of Raskin distribution, it is hoped that it will be easier for Perum Bulog in the Pidie district to make decisions to determine the location of Raskin distribution. In making the Geographical Information System for the Distribution Location of Raskin, the programming language used is PHP and the database is MySQL. The tables used in the creation of a geographic information system for the distribution of Raskin include admin tables, village tables, sub-district tables, and location tables. With the geographical information system for the location of the Raskin distribution, Perum Bulog can find out the distance between the Bulog warehouse and the location of the Raskin distribution point (The year 2019).

Monggas Village is included in the Kopang District with a total population of 7125 people and 3272 poor people. The number of poor people in Monggas Village is relatively high with sebran in each hamlet. The Monggas Village Government selects data on the poor with regular data collection. The poor people's data is stored in a Microsoft Office Excel file. The file contains community biodata and complete addresses but cannot display data in the form of maps, routes, or pictures. If you are going to visit, the search for the location of residence is done conventionally, namely searching for addresses starting from the hamlet, RT, and getting information from the community. This is an obstacle for relevant stakeholders to trace the addresses of the poor for various purposes of assistance and data collection.

The implementation of the development of this geographic information system aims to display the distribution area of the poor in Probolinggo Regency in three dimensions in the form of a digital map. So that the information displayed is easy to analyze and the distribution of the population can be identified in a visual form. This application development method uses the Software Development Life Cycle method which consists of Planning, Analysis, Design, and Implementation. This application is made using QuantumGIS, P-mapper, and MapServer with PHP programming language. This Geographic Information System can display a mapping of poor areas based on 4 levels of poverty, namely moderate poverty, near-poor, poor, and very poor. Thus, this application is very useful for the Regional Development Planning Agency of Probolinggo Regency to understand the meaning of the data that has been displayed visually with a map by looking at areas that have been grouped with the same poverty level (Hikmah, Marzuki, and Aristi 2020).

A. Geographic Information System (GIS)

Geographic information, in its simplest form, is information relating to a particular location (Martin, 1996:1). In a broad sense, a Geographic information system is a tool in processing spatial data into information (DeMers, 1997:7). GIS is not just the use of computers to make maps, but more than that GIS should be able to help in analysis. According to Martin (1996:3) quoted by (Bagye et al. 2019).

\section{B. Definition of a Poor Household}

According to BPS, the poverty line limit is based on the value of the rupiah spent to meet 2100 calories per capita per day plus the fulfillment of other minimum basic needs such as housing, fuel, clothing, education, health, and transportation. The value of the expenditure is a "very poor limit" if all of the expenditure is only able to meet the minimum need for food. To be more focused on poverty alleviation efforts, there are several stages carried out, namely:

1. The category of underprivileged, received temporary assistance.

2. The category is already unable, gets Raskin and a health card.

3. The category of being incapable, gets empowerment. In 2000, BPS conducted a Study on Determining the Criteria for the Poor (SPKPM 2000) to find out household characteristics that we're able to define poverty conceptually (basic needs/poverty line approach) (Mardiana 2011).

Meanwhile, according to the Pekanbaru city BPS, the criteria for household poverty (Ruta) are 14 variables, as shown in Table 1. 
Table 1. Point criteria

\begin{tabular}{|l|l|}
\hline \multicolumn{1}{|c|}{ Poverty Variable } & \multicolumn{1}{c|}{ Poverty Criteria } \\
\hline The floor area of residential building type & $<8 \mathrm{~m} 2 \mathrm{per}$ capita \\
\hline Residential building floor type & Cheap earth/spices/wood \\
\hline Types of walls of residential buildings & Seasonings/sago palm/low-quality wood/wall/without plaster \\
\hline Defecation facilities & Don't have/with another household \\
\hline Source of light & Not electricity \\
\hline Source of drinking water & Unprotected wells/ springs/rivers/rainwater \\
\hline Fuel for everyday cooking & $\begin{array}{l}\text { Firewood/charcoal/ } \\
\text { kerosene }\end{array}$ \\
\hline Consumption of meat/chicken every week & Never/once a week \\
\hline $\begin{array}{l}\text { Purchase of new clothes for each household member in a } \\
\text { year }\end{array}$ & Never bought/one set \\
\hline Frequency of meals in a day for each household member & One time / two meals a day \\
\hline Ability to pay for treatment at the polyclinic & Unable to treat \\
\hline The main occupation of the head of the household & $\begin{array}{l}\text { Farmers with land area < 0.5 Ha, farm laborers, fishermen, } \\
\text { construction workers, or other workers with household income } \\
<\text { Rp. } 600,000,- \text { every month }\end{array}$ \\
\hline Family head education & $\begin{array}{l}\text { Not in school / not finished elementary school / finished } \\
\text { elementary school }\end{array}$ \\
\hline Ownership of assets/movable property/immovable property & $\begin{array}{l}\text { Do not have savings/goods that are easily sold with a value }> \\
\text { Rp. 500,000,- such as motorcycles, gold jewelry, livestock, } \\
\text { boats/motorboats, or other capital goods }\end{array}$ \\
\hline
\end{tabular}

If there is a household that has at least 7 categories of variables, then the household is categorized as poor, a household that has 9 variable categories is categorized as moderately poor, while a household that has all categories, namely 14 , is categorized as very poor.

\section{Leafleat}

The leaflet is generally an open source javascript library that is useful for building web-based interactive map applications. Leaflet supports mobile platforms and desktop platforms, HTML5 and CSS3 as well as OpenLayer and Google Maps API which are javascript libraries for building map applications that are very popular today.

\section{SUS (System Usability Scale) method}

The SUS method is one of the most popular usability testing tools. SUS was developed by John Brooke in 1986. This SUS is a reliable, popular, effective, and inexpensive usability scale (Saputra 2019).

\section{RESEARCH METHODS}

This research will be carried out in Palaran District as a place to be researched. The tools used are hardware (hardware) and software applications (software) as follows:

1. Hardware:
a. Asus Laptop (i3 Processor, 4GB RAM)
b. iPhone XR phone (Documentation)

2. Software:
a. XAMPP version 3.3.0
b. Codeigniter 3
c. Sublime Text version 3
d. Microsoft Office (Word, Visio) 2019

\section{e. Leaflet version 1.8}

3. Ingredients
a. District Boundary Data Source: Google Earth
b. Poor Household Data Data Source: Palaran District

\section{A. Research procedure}

In this study, the stages of making a web-based geographic information system for the location of Poor Households in Samarinda City used the waterfall method. The waterfall method or the so-called waterfall method where this describes a systematic and sequential approach in building a system can be seen as shown in Picture 1. 


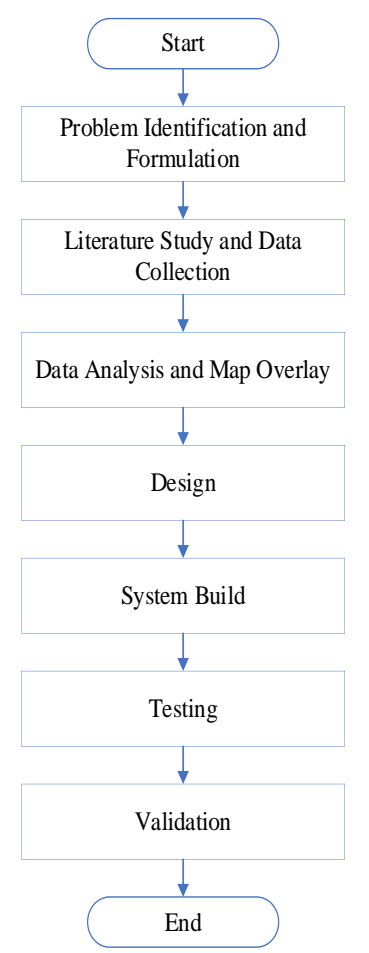

Picture 1. Research Method

1. Problem Identification and Formulation

This stage is the initial step for research, namely the identification and formulation of the problem. What problems arise in this research, and these problems are formulated as follows:

a. What is the poverty rate for households in the Palaran sub-district?

2. Literature Study and Data Collection

The literature study conducted aims to make it easier to determine the data analysis method to be used based on previous research and data collection is the initial stage in carrying out the development process in the system to be created, while the data collection process includes primary data and secondary data where primary data can be carried out using directly to the field and make questionnaires which are submitted to each kelurahan and secondary data can be obtained from the relevant agencies.

3. Data Analysis and Map Overlay

Data analysis is a research process that is carried out after all the necessary data is obtained to solve the problem under study and the overlay is used to display a digital map and its attributes and produce several combined maps that have attribute information from several of these maps and calculations are carried out during the overlay process.

4. Design

System Design helps in hardware and system requirements and also helps in defining the overall system architecture.

5. System Build

Making the system that is done is to create a mapping information system application with the web that runs well. Making this system is the main stage because at this stage the system development process can solve problems and process the data that has been collected. At this stage, the process of the design results that have been made is implemented.

6. Testing

At this stage, the system testing process is carried out to find out whether the system is running well or not, if there is a problem with the system, a redesign of the system will be carried out to fix the problems that occur.

\section{Validation}

At this stage, a validation process is carried out which consists of:

a. Data Authenticity

At this stage is checking and matching the data whether it is appropriate or not.

b. Application

At this stage, it is done to find out whether the application made has provided benefits and convenience to the user by conducting a questionnaire

\section{B. System Development Method}

The research method applied in this research is the development of the waterfall method. The waterfall method is a systematic and sequential information system development model. The Waterfall method has the following stages:

1. Requirements analysis and definition System services, constraints, and objectives are determined by the results of consultation with users which are then defined in detail and serve as system specifications.

2. System and software design the system design stage allocate system requirements both hardware and software by forming the overall system architecture. Software design involves identifying and delineating the basic system abstractions of software and their relationships.

3. Implementation and unit testing at this stage, the software design is realized as a series of programs or program units. Testing involves verifying that each unit meets its specifications.

4. Integration and system testing The individual units of the program or programs are combined and tested as a complete system to ensure whether it meets the requirements of the software or not. After testing, the software can be sent to the customer 5) Operation and maintenance usually (though not always), this stage is the longest. The system is installed and used for real. Maintenance involves correcting errors that were not found in the previous stages, improving the implementation of the system unit, and improving system services as new requirements (Sasmito 2017).

\section{System Design}

The following is a web-based application design for a poor household geographic information system application in the Palaran sub-district. 
1. Data Flow Diagram (DFD) level 0

In the picture, there is one process, namely the Web-Based Geographic Information System for Poor Household Locations and there are two entities, namely admin and user, which can be seen as shown in Picture 2.

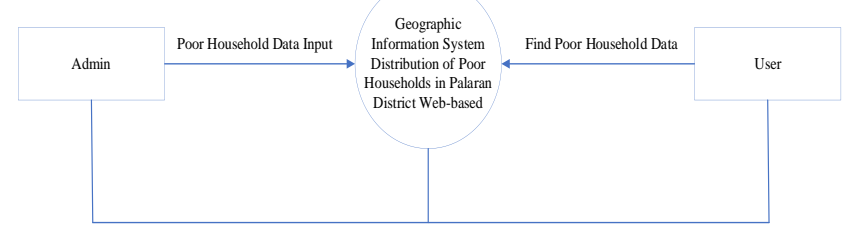

Picture 2. Data Flow Diagram Level 0

a. Process

GIS Location of Poor Households is a system that provides information to users about the existence of poor households.

b. Entity

\section{1) Admin}

Admin fully manages to input, edit, delete and update poor household data.

2) User

Users looking for information about poor households.

2. Data Flow Diagram (DFD) level 1

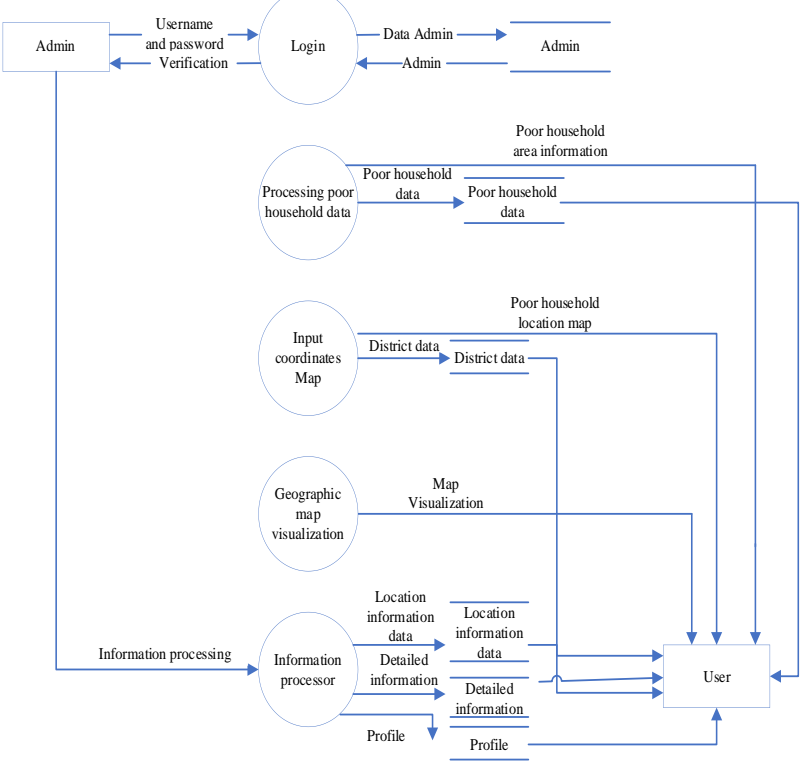

Picture 3. Data Flow Diagram Level 0
Explanation of picture 3, Data Flow Diagram Level 1. Data Flow Diagram Level 1 consists of 5 processes and 2 entities including:

a. The Admin Entity performs several tasks, namely:

1) The admin inputs the admin data username and password which is used as a login account by the admin and will be processed by the Login system and then forwarded to the Admin datastore.

2) Admin manages the appearance of the homepage design and adds information about poor household areas as best and interesting as possible so that users can better understand and understand the information.

3) The admin performs input, editing, deletion, and updating of attribute data and then it will be processed by the poor household area map system and will be continued into the attribute datastore.

4) Admin adds information processing to the information processing system.

b. The User Entity performs several tasks, namely:

The user searches for poor household data and location map information which will then be processed by the system for processing poor household data and information processing, the system processing data for poor households and information processing for checking and searching data in the database, and then the system processing household data. Poor and information processors provide information back to the user.

\section{RESULTS AND DisCUSSION}

1. Application creation results

The results of the application of the Geographic Information System for the Distribution of Poor Households in Palaran District are as follows:

a. Home View

On the Home page, a map of the location of poor household data can be seen in Picture 4 . 


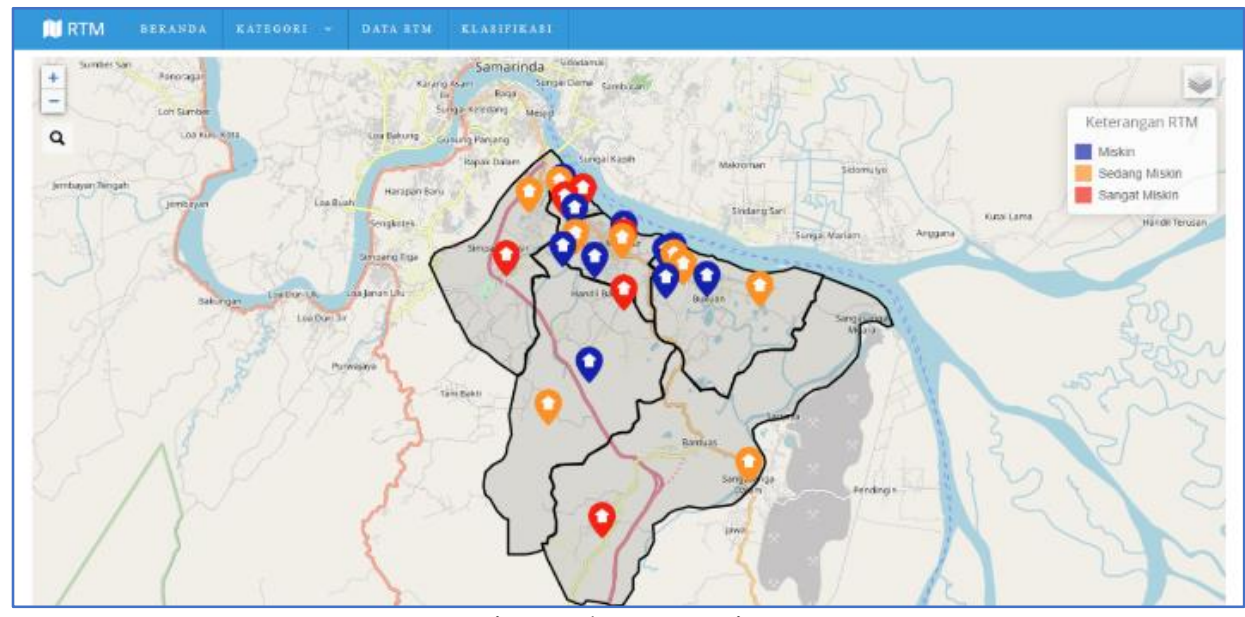

Picture 4. Home View

b. Detail information page.

The detail information page displays markers that have been previously selected to view detailed information which includes information such as village, name, family number, address, and other information. Can be seen in Picture 5.

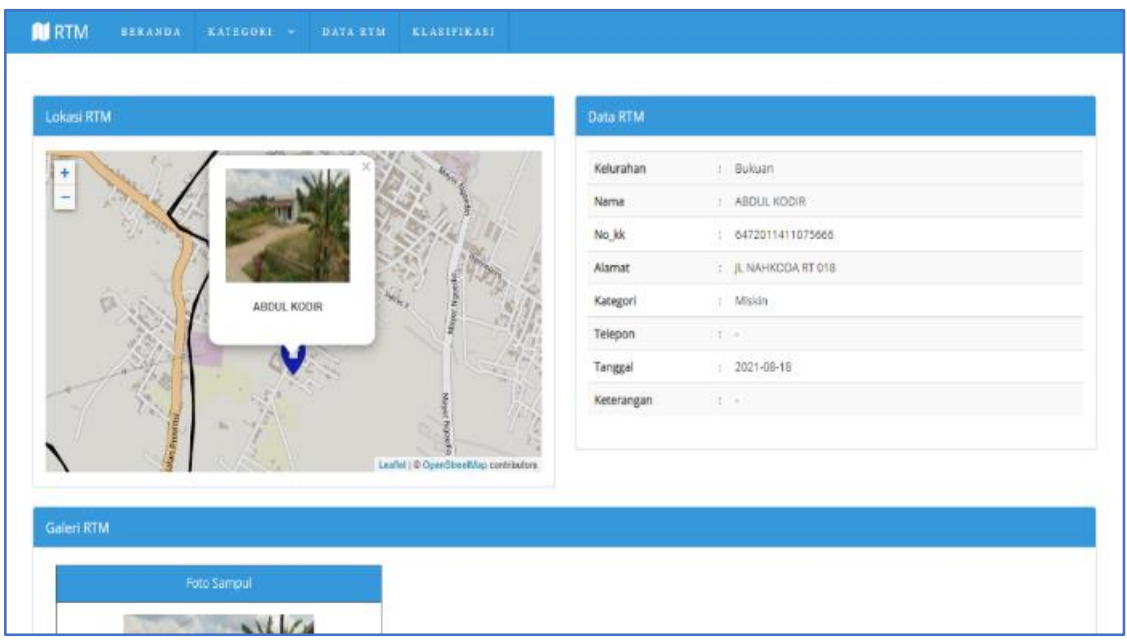

Picture 5. Information Details

c. Login page

This page displays the username and password for the admin to access the data. Can be seen in Picture 6 .

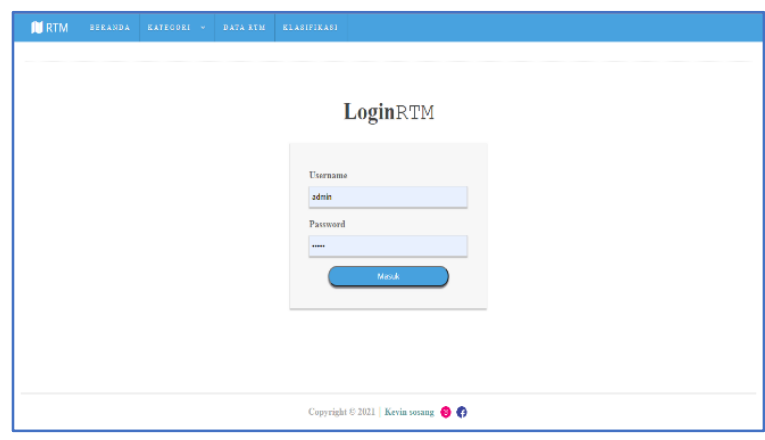

Picture 6. Login Page

d. Poor household data page

The poor household data page displays a table that provides area information, name, family number, address, and other information. On this page, there is also an add data button and a data print button, besides that there are also three actions, namely detail, edit and delete data. Can be seen in Picture 7. 


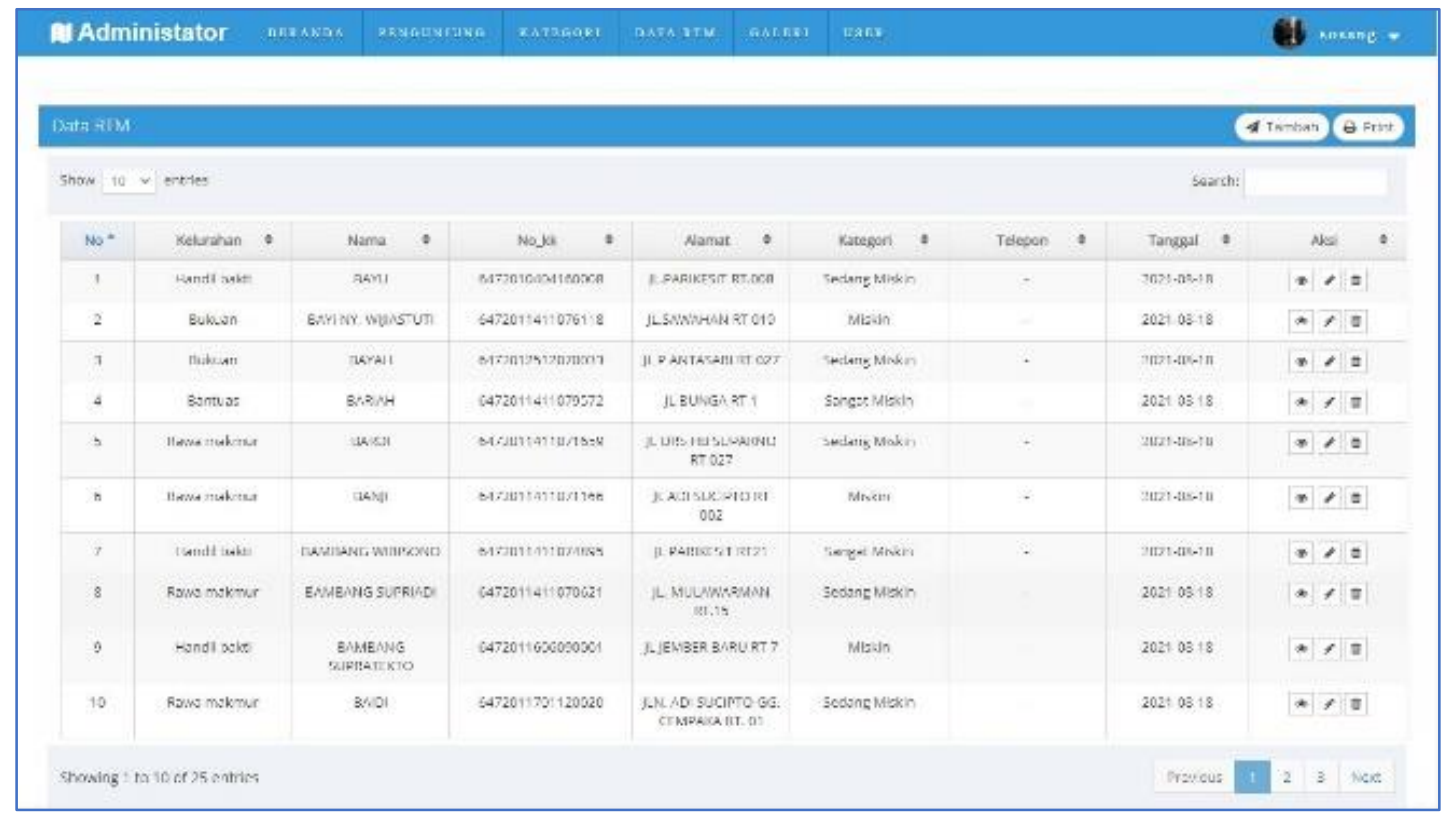

Picture 7. Poor Household Data

e. Add data page

The Add Data page displays a form to enter new data and on this page, there are save, reset, and return buttons. Can be seen in Picture 8 (a) and (b)

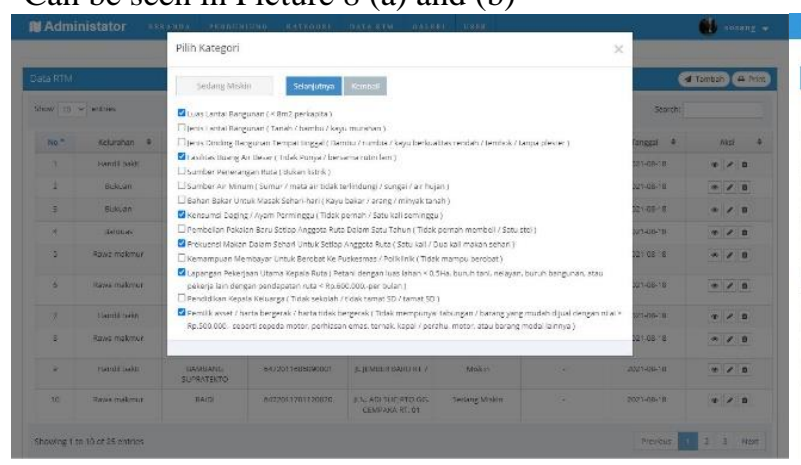

(a)

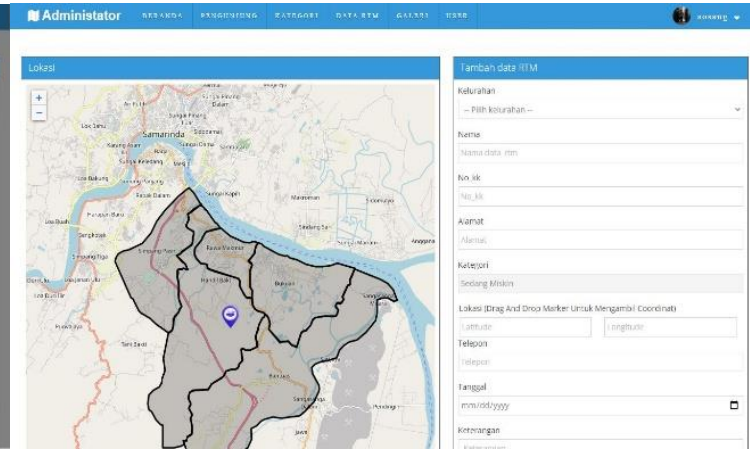

(b)

Picture 8. Add Category Data (a) and GIS Data (b)

f. Data editing page

The data edit page displays a form to change the data that has been inputted, on this page, there are also save, reset, and return buttons. It can be seen in Picture 9 (a) and (b)

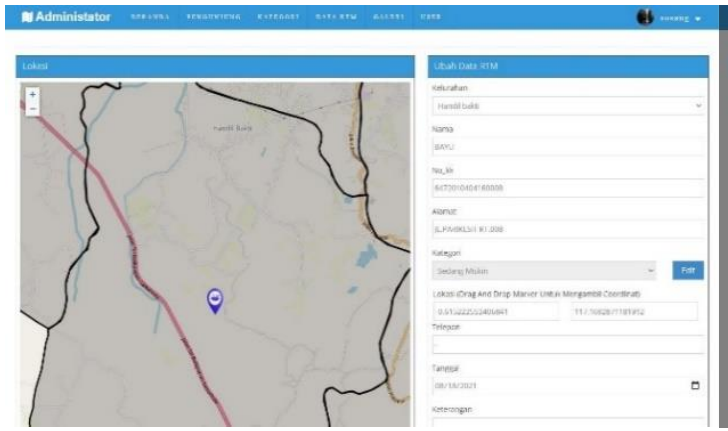

(a)

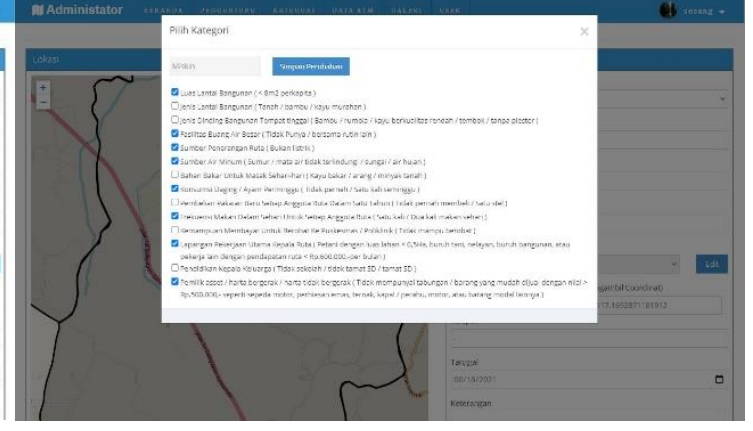

(b)

Picture 9. Edit data (a) and edit Category Data (b)

2. $\quad$ System Test

System testing is carried out to ensure the application runs properly. With this test can also find out the weaknesses of this system. So, if there is an error in the system, it can be repaired. In this test, black box and questionnaire methods are used. 
a. User blackbox testing

The results of the black box testing are as follows. Can be seen in table 2 .

Table 2. Blackbox User table

\begin{tabular}{|l|l|l}
\hline Testing & Results & Result \\
\hline Home View & Show Map & Success \\
\hline Category View & Show Category & Success \\
\hline $\begin{array}{l}\text { Poor Household Data } \\
\text { Display }\end{array}$ & $\begin{array}{l}\text { Showing Poor } \\
\text { Household Data }\end{array}$ & Success \\
\hline Login & $\begin{array}{l}\text { Input Username \& } \\
\text { Password }\end{array}$ & Success \\
\hline
\end{tabular}

b. Admin Blackbox Test

The results of the black box testing are as follows. Can be seen in table 3 .

Table 3. Admin Blackbox Table

\begin{tabular}{|l|l|l}
\hline \multicolumn{1}{|c|}{ Testing } & \multicolumn{1}{c}{ Result } & Result \\
\hline Gallery View & $\begin{array}{l}\text { Input Gallery } \\
\text { Update Gallery } \\
\text { Delete Gallery }\end{array}$ & Success \\
\hline $\begin{array}{l}\text { Poor } \\
\text { Household } \\
\text { Data Display }\end{array}$ & $\begin{array}{l}\text { Input Poor Household Data } \\
\text { Update Poor Household Data } \\
\text { Delete Poor Household Data }\end{array}$ & Success \\
\hline User display & $\begin{array}{l}\text { Input User } \\
\text { Update User } \\
\text { Delete User }\end{array}$ & Success \\
\hline
\end{tabular}

c. Determination of Classificationg

Priority determination of poor households is carried out by calculating each poor household data based on predetermined criteria.

The criteria used as indicators of poverty in this study consisted of 14 criteria. Several other studies also use the criteria set by the Central Statistics Agency to determine priorities for poor households.

The determination of poor households is divided into 3 categories, namely moderate poor, poor, and very poor. The following are things that are used to determine the classification of poor households, namely:

1. If there are 1-7 variables selected then the household data can be said to be a household (medium poor).

2. If there are 8-9 selected variables then the household data can be said to be a (poor) household.

3. If there are 10-14 criteria selected then the household data can be said to be a household (medium poor).

\section{CONCLUSIONS}

In making the application of the geographic information system for the distribution of poor households in the Palaran sub-district based on the web, the results obtained to facilitate the community in distributing aid in the Palaran District area and are expected to be one of the more efficient supporting aspects in handling assistance to poor households. This web-based application of the geographic information system for the distribution of poor households can display detailed information such as the categories of poor households classified according to 14 criteria variables set by the Central Statistics Agency so that the data in the selection of categories of poor households is more accurate so that it is easier for the public to distribute help right on target

\section{REFERENCES}

Adiana, Pande Putu Erwin, and Ni Luh Karmini. 2012. "The Influence of Income, Number of Family Members, and Education on Consumption Patterns of Poor Households in Gianyar District." Udayana University Development Economics E-Journal 1(1):39-48.

Bagye, Wire, Lalu Zaenul Haqiqi, and Maulana Ashari. 2019. "Web-Based Geographic Information System for the Distribution of the Poor (Damaskin) in Monggas Village." Journal of Information Management and Information Systems 2(2):9. doi:10.36595/misi.v2i2.99.

Fithriyyah, Ulfa, Fajril Akbar, and Haris Suryamen. 2016. "Development of an Information System for the Distribution of Poor Households in Puhun Tembok Bukittinggi Village." Sisfo 06(01):89-104. doi: 10.24089/j.sisfo.2016.09.007.

Hikmah, N., I. Marzuki, and C. Aristi. 2020. "Development of a Geographic Information System on the Distribution of the Poor in Probolinggo Regency." J-SAKTI (Journal of Science ... 4(September):434-44

Mardiana, Rina. 2011. "GIS-Based Poor Information System (Case Study: Pekanbaru Municipality).”

Sasmito, Ginanjar Wiro. 2017. "The Application of the Waterfall Method in the Design of an Industrial Geographic Information System in Tegal Regency." Journal of Informatics:Journal of IT Development (JPIT) 2(1):6-12.

Year, Pidie Regency. 2019. “JRR, Vol I, No I, June 2019, ISSN: 2685-1024.” I(I):69-80.

Saputra, Ade. 2019. "Usability Implementation in PENTAS Application Using the System Usability Scale (SUS) Method (Usability Implementation in PENTAS Application Using the System Usability Scale (SUS) Method)." JTIM: Journal of Information Technology and Multimedia 1(3): 206-12. 